\title{
Effect of NPK Fertilization on Cassava Mosaic Disease (CMD) Expression in a Sub-Saharan African Region
}

\author{
M. Muengula-Manyi ${ }^{1}$, K. K. Nkongolo ${ }^{2^{\star}}$, C. Bragard ${ }^{3}$, P. Tshilenge-Djim ${ }^{1}$, \\ S. Winter ${ }^{4}$ and A. Kalonji-Mbuyi ${ }^{1,5}$ \\ ${ }^{1}$ Phytopathology Unit, Faculty of Agronomy, University of Kinshasa, P.O. 117 Kinshasa XI, \\ Democratic Republic of Congo. \\ ${ }^{2}$ Department of Biology, Laurentian University, Sudbury, Ontario, P3E 2C6, Canada. \\ ${ }^{3}$ Earth and Life Institute, Applied Microbiology-Phytopathology, Université catholique de \\ Louvain, Croix du sud 2 bte 3, 1348 Louvain-la-Neuve, Belgium. \\ ${ }^{4}$ Plant Virus Collection, DSMZ Deutsche Sammlung von Mikroorganismen und Zellkuturen \\ $\mathrm{GmbH}, 38104$ Braunschweig, Germany. \\ ${ }^{5}$ Regional Nuclear Energy Center, Kinshasa (CRENK), P.O. Box 868, Kinshasa XI,
} $R D$ Congo.

Research Article

Received $21^{\text {st }}$ February 2012

Accepted $12^{\text {th }}$ April 2012

Online Ready $19^{\text {th }}$ April 2012

\section{ABSTRACT}

The influence of NPK fertilizer on the incidence, severity and gravity of cassava mosaic disease (CMD) was investigated using eight genetically improved cassava varieties and eight local farmer's varieties. The study was carried out in a savannah region (Gandajika) in D.R. Congo at two locations. The varieties were planted with and without NPK fertilization. Application of NPK fertilizer significantly $(P<0.05)$ increased CMD incidence, severity (AUDPC) and gravity overtime compared to the trials without fertilizers for all the improved cassava varieties evaluated. The CMD incidence remained below $30 \%$ of infected plants for improved cassava varieties and reached $100 \%$ of plants for local varieties during the six months trial. The same trend was observed for CMD gravity (number of infected leaves per plant) that was below $50 \%$ for improved varieties while reaching $100 \%$ for all the local varieties at 6 MAP. High incidence and gravity of CMD were observed on local varieties just one month after planting. NPK fertilizers increased significantly the CMD incidence and gravity compared to control site during the first month after plantation. Thereafter, the effect of NPK fertilizer on CMD symptom expression was not noticeable since all the plants from local varieties were infected regardless of the fertilization regimen. 
Keywords: Cassava mosaic disease (CMD); NPK fertilizer; improved varieties; local varieties; symptom expression; Gandajika (DR-Congo).

\section{INTRODUCTION}

Cassava (Manihot esculenta Crantz) is an important staple food in tropical countries and is a major food item for at least 200 million African people. It can grow on marginal soils where cereals and other crops cannot thrive. It withstands drought conditions and diseases and pests (Ntawuruhunga et al., 2006) which make it a suitable crop for poor farmers to cultivate under marginal environment in Africa. Cassava is the fourth largest source of calories after rice, sugarcane and maize (El-Sharkawy, 1993). The tuberous roots of cassava are the major source of dietary starch. In DR-Congo and several Eastern African countries, cassava leaves are also consumed as green vegetable to provide important sources of proteins, minerals, and vitamins (Achidi et al., 2005). Among the cassava-growing regions of the world, Africa accounts for more than $50 \%$ of the global cassava production of 233.8 million metric tons (FAOSTAT, 2009).

Cassava crop is afflicted with many pests and diseases including cassava spider mite, cassava mealy bug, African cassava mosaic disease, cercospora leaf spot disease, cassava bacterial blight bacterial, anthracnose, cassava brown streak disease, cassava mealy bug (Phenacoccus manihoti), green mite (Mononychellus tanajoa) and nematodes (particularly Meloidogyne spp.) among others (Nassar and Ortiz, 2007). African Cassava mosaic disease (ACMD) is the most severe and widespread disease caused by viruses limiting production of the crop in sub-Saharan Africa. The average yield of cassava in farmer's fields in the DRCongo like in most African countries is 7 to 8 tonnes per hectare which is far below the potential of the crop and the 25-30 tha ${ }^{-1}$ reported from research station trials (Tata-Hangy et al., 2007). The most important single reason for this is probably the almost ubiquitous presence of African cassava mosaic disease (Thresh et al., 1997; Fargette et al., 1988; Legg et al., 2000 and 2006; Dixon et al., 2003; Oerke, 2006). Two main methods are used to control CMD. They include the use of CMD resistant or tolerant varieties and the implementation of sanitation techniques. The latter method consists in taking for planting only cuttings from healthy plants and subsequently removing any infected plants (Ntawuruhunga et al., 2007).

Soil, cultural practices, and socio-economic factors play also a key role in cassava production. In many tropical countries, soil fertility is usually poor and requires fertilization to achieve a high level of cassava production. Horst (1990) noted that soil fertility can be manipulated to facilitate the control of some fungal, bacterial and viral diseases. However, according to several reports, incidence and severity of virus diseases are enhanced with increased levels of plant nutrition (Bawden 1960; Otim-Nape, 1987; Sseruwagi et al., 2003). Omorusi and Ayanru, (2011) on the other hands reported that the incidence of CMD infection was depressed by high dosage of NPK (100 kg ha-1) when compared to plants in soil with low NPK $\left(10 \mathrm{~kg} \mathrm{ha}^{-1}\right)$. The majority of these trials involved only one to two improved varieties with limited attention to farmer's varieties and conditions. The main objective of the present study is to assess the effect of NPK fertilizer on CMD symptom expression and development overtime using several improved and local cassava varieties. 


\section{MATERIALS AND METHODS}

\subsection{Experimental Sites}

The study was carried out at two sites in Gandajika (Eastern Kasai) in the DR. Congo. Site 1 was located at INERA research station $\left(23^{\circ} 57^{\prime} \mathrm{E}, 06^{\circ} 48^{\prime} \mathrm{S}\right.$ and $754 \mathrm{~m}$ altitude) and site 2 in Mpiana ( $23^{\circ} 56^{\prime} \mathrm{E}, 06^{\circ} 36^{\prime} \mathrm{S}$ and $685 \mathrm{~m}$ altitude). The region falls within the Aw4 climate type according to Köppen classification characterized with 4 months of dry season (from mid-may to august) coupled with 8 months of rainy season, sometimes interrupted by a short dry season in January/February. Daily temperature averages $25^{\circ} \mathrm{C}$ and annual rainfall is close to $1500 \mathrm{~mm}$. Typically, Gandajika soils consist of a collection of sandy on clay sediment more often based on a shallow lateritic old slab. The adsorption complex is fairly well saturated and there are still some weatherable minerals.

\subsection{Plant Materials Used in the Study}

The plant materials used in the present study consisted of 16 different local and improved cassava varieties. The eight local varieties that were evaluated include Kamana-mabanza, Kavuandula, Luenyi, Madame, Muana-mpiana, Mutombo-tshomba, Nzaza and Tshilobo. Eight genetically improved varieties (Butamu, Disanka, Gandajika, F 100, Mvuazi, Sadisa, TME 419 and Zizila) currently released in DR-Congo were also evaluated. These cassava improved varieties from the DR-Congo breeding program were selected for their resistance to the CMD. The local varieties were provided by farmers while the improved varieties were from the National Cassava Programme (PRONAM). Hardwood stem cuttings of local varieties were collected from farmers' fields and they were selected from healthy plants for use as planting material.

\subsection{Experimental Design}

The study was conducted from September 2009 to march 2010. In each site, two separate trials were performed. The cassava materials were planted in a split-plot randomised block design with three replications. For each trial, the main plots represented cassava varieties. Each plot was subdivided into two sub-plots representing each treatment namely NPK fertiliser (17-17-17) and the unfertilized control (noted NoF). NPK (17-17-17) was applied at the time of planting using the recommended dosage of $300 \mathrm{Kg} \mathrm{ha}^{-1}$ (Lema et al., 2004). Hardwood stem cuttings were planted at spacing of $1 \mathrm{~m} \times 1 \mathrm{~m}$. In each main plot, the distance between 2 sub-plots was $1.5 \mathrm{~m}$ while the distance between 2 neighbouring plots was $2 \mathrm{~m}$. A total of 12 hardwood stem cuttings were planted in each main plot.

\subsection{Disease Incidence, Severity and Gravity}

Cassava mosaic disease (CMD) incidence, severity and gravity were recorded at 1,3 and 6 months after planting (MAP). The CMD incidence represented the proportion of plants showing symptoms of the disease. The CMD gravity per plant was assessed by the proportion of leaves with typical symptoms of the disease. CMD symptom severity was assessed using a scale of increasing severity of 1 to 5 described by Hahn et al. (1980), where 1 (no symptoms) represents an apparently healthy cassava plant and 5 a severely infested cassava plant with a reduction of leaflets. The average ratings of severity were used to calculate the Area under Disease Progress Curve (AUDPC) according to the following 
formula: AUDPC $=\sum_{i=1}^{n}\left[\left(x_{i}+x_{i+1}\right) / 2\right] * t$ (Shaner and Finney, 1977) where $x_{i}$ is CMD severity at the time $i, n$ is the number of data taken and $t$ is the number of days between the registration of $x_{i}$ and $x_{i+1}$.

\subsection{Data Analysis}

Data on CMD incidence and gravity were tested for homogeneity of variance before analyses. They were transformed using the formula $y^{\prime}=\operatorname{arcsine} \sqrt{y}$ (Legendre and Legendre, 1998), where $y$ is the proportion of infected plants (level of incidence) or the proportion of leaves with symptoms (level of gravity). The transformed data were subjected to the analysis of variance (ANOVA) using the Statistics 8 (free version) software. Main effects were separated by least significant differences (LSD) at the $P \geq 0.05$ level. Data from fertilized and no-fertilized trials were compared using the Student T-test.

\section{RESULTS}

The results for CMD incidence and gravity are summarized in Tables 1 and 2. Data for CMD severity are described in Figures 1 and 2. The overtime expression of the disease expressed in CMD incidence and gravity are illustrated in Figures 3 and 4 for all the treatments.

\subsection{Cassava Mosaic Disease Incidence}

It was noted that all varieties developed typical symptoms of CMD overtime. CMD symptoms were observed on local varieties and not on improved varieties one month after planting (1 MAP) (Table 1). At three months after planting (3 MAP), typical symptoms of CMD were observed for fertilized trails but absent on plants from trials without fertilizers for improved varieties. This trend was noted over the six months of experimentation. The highest incidence of CMD at 3MAP in fertilized plots for improved varieties was observed in TME 419 (20.5\%) and Mvuazi (24.9\%), while the lowest incidence was recorded in Butamu (5.5\%) and Disanka (13.3\%), in site 1 (INERA) and site 2 (Mpiana), respectively. At 6 MAP, only F100 variety showed slight symptoms (5.5\% of incidence) for improved varieties under non fertilization regimen (Table 1). In fertilized trial, the highest incidence was observed in Sadisa (25.5\%) and Mvuazi plants (24.9\%), at site 1 (INERA) and site 2 (Mpiana), respectively while the lowest incidence was recorded on plants from Gandajika variety $(16.6 \%)$ in the two sites. For the trial without fertilizers, the highest incidence at site 1 (INERA) was observed Mvuazi plants (12.2\%) while the lowest incidence was recorded in varieties Disanka and TME 419 (5.5\%). However, at site 2 (Mpiana), only plants from F 100 developed CMD symptoms with an incidence estimated at $5.5 \%$. In each site, application of NPK fertiliser significantly $(\mathrm{P}<0.05)$ increased overtime CMD incidence for each improved variety. Details of the CMD incidence for local varieties are described in Table 1. CMD symptoms were observed in all varieties at both sites 1 and 2, one month after planting (1 MAP) with a significant variety $x$ site interaction. At this stage (1 MAP), the highest incidence of CMD in fertilized trial was observed on Nzaza (91.7\%) and Muana-mpiana (88.8\%) plants at sites 1 and 2, respectively while the lowest incidence was observed on Muana-mpiana plants (20\%) at site 1 and Mutombo-tshomba plants (46.6\%), at site 2. In trials without fertilizers, the highest incidence was observed on Nzaza (68.8\%) and Kavuandula (61\%) plants while the lowest level of incidence was recorded in Kavuandula (8.3\%) and Kamana-mabanza and Mutombotshomba (11.1\%) plants, at sites 1 and 2, respectively. In fertilized trial, at 3 MAP, the 
highest level of incidence was observed on plants from Madame, Nzaza, Tshilobo, Kavuandula, Luenyi and Mutombo-tshomba (100\%) while the lowest level of incidence was observed on Muana-mpiana and Kamana-mabanza (93.3\%) plants. However, at site 2 (Mpiana), all varieties (100\%) were infested three months after planting while at site 1 (INERA) this maximum level of incidence was reached only six months after planting.

\subsection{Cassava Mosaic Disease Gravity (\% of Leaves with CMD Symptoms)}

It was noted that CMD gravity for improved varieties was less than $50 \%$ regardless of the site (Table 2). Typical CMD symptoms were observed 3 months after planting in fertilized trials only for improved varieties. T test analysis revealed that CMD gravity was significantly higher in fertilized trials compared to trials without fertilizers for improved varieties during the experimentation period (6 months). At 3 MAP, the highest levels of gravity were observed in Zizila $(28.4 \%)$ and Sadisa $(21.2 \%)$, while the lowest levels of gravity were recorded in Butamu (3.3\%) and Disanka (10.4\%), at site 1 and site 2, respectively. At 6 MAP, the highest levels of CMD gravity was observed on Zizila plants (43.7\%) at site 1 and on Sadisa plants $(41.2 \%)$ at site 2 while the lowest levels of gravity were found on Butamu (22.6\%) and F 100 $(24.2 \%)$ plants, for sites 1 and 2, respectively. In trials without fertilizers, the highest CMD gravity at 6 MAP in site 1 (INERA) was observed on Mvuazi plants (12.4\%), while the varieties Disanka and Gandajika showed the lowest gravity (6.7\%). In site 2 (Mpiana), only F 100 plants show a low level of symptoms with CMD gravity of $2.9 \%$.

In general the local varieties show higher gravity values compared to improved varieties. Fertilized trials show higher levels of gravity compared to no fertilized trials during the first three months. At 6 MAP, all the local varieties show $100 \%$ gravity for both fertilized and no fertilized trials. In fertilized trials, 1 MAP, the highest gravity was observed on Nzaza (54.1\%) and Muana-mpiana (61.5\%) plants while the lowest gravity was observed on Muana-mpiana (15.3\%) and Nzaza (39.6\%) plants, at sites 1 and 2, respectively. In trials without fertilizers, the highest CMD gravity at 1 MAP was observed in Nzaza (37.9\%) and Kavuandula (36.8\%) while the lowest gravity was found in variety Kavuandula (9\%) and varieties Luenyi and Mutombo-tshomba (10.4\%), respectively at sites 1 and 2. At 3 MAP the highest gravity was observed in Madame (92\%) and Muana-mpiana and Mutombo-tshomba (100\%), in fertilized plots from sites 1 and 2, respectively. The lowest degree of gravity was registered in Luenyi $(64.3 \%)$. However, in trials without fertilizers, the highest gravity was observed in Nzaza $(73.8 \%)$ and Kavuandula (78.9\%) while the lowest gravity was found in Kavuandula (47.7\%) and Kamana-mabanza (51.3\%), at sites 1 and 2, respectively. At 6 MAP, the CMD gravity in the two experimental sites was $100 \%$ for all the local varieties.

\subsection{Cassava Mosaic Disease Severity}

CMD severity was measured by the Area under Disease Progress Curve (AUDPC). As with CMD incidence, the severity of CMD was higher in fertilized trials compared to non fertilized plants. The application of NPK fertilizers significantly increased the CMD severity for different varieties (Figures 1 and 2). The Area under Disease Progress Curve (AUDPC) calculated for site 1 (INERA) over a period of 6 months for the cassava improved varieties revealed significant differences $(P<0.05)$ among varieties, between treatments, and an interaction between variety and treatment. For local varieties, the AUDPC revealed significant differences $(P<0.05)$ between treatments and for the variety $x$ treatment interaction. In site 2, the AUDPC revealed significant differences $(P<0.05)$ among varieties and an interaction between varieties and treatment, for both improved and local varieties. 
Table 1. Effect of NPK fertilizer on Cassava Mosaic Disease incidence using improved and local cassava cultivars in Gandajika (DR-Congo)

\begin{tabular}{|c|c|c|c|c|c|c|c|c|c|c|c|c|}
\hline \multirow{3}{*}{ Type of cultivar } & \multicolumn{6}{|c|}{ Site 1 (INERA) } & \multicolumn{6}{|c|}{ Site 2 (Mpiana) } \\
\hline & \multicolumn{2}{|c|}{$1 \mathrm{MAP}$} & \multicolumn{2}{|l|}{3 MAP } & \multicolumn{2}{|l|}{6 MAP } & \multicolumn{2}{|c|}{$1 \mathrm{MAP}$} & \multicolumn{2}{|l|}{3 MAP } & \multicolumn{2}{|l|}{6 MAP } \\
\hline & NPK & NoF & NPK & NoF & NPK & NoF & NPK & NoF & NPK & NoF & NPK & NoF \\
\hline \multirow{2}{*}{$\begin{array}{l}\text { Improved } \\
\text { TME } 419\end{array}$} & & & & & & & & & & & & \\
\hline & 0 & 0 & $20.5(0.47)$ & 0 & $20.5(0.47)$ & $5.5(0.23)$ & 0 & 0 & $22.1(0.49)$ & 0 & $22.1(0.49)$ & 0 \\
\hline Mvuazi & 0 & 0 & $18.8(0.44)$ & 0 & $24.4(0.51)$ & $12.2(0.35)$ & 0 & 0 & $24.9(0.52)$ & 0 & $24.9(0.52)$ & 0 \\
\hline Sadisa & 0 & 0 & $18.8(0.44)$ & 0 & $25.5(0.52)$ & 0 & 0 & 0 & $23.3(0.50)$ & 0 & $23.3(0.50)$ & 0 \\
\hline Disanka & 0 & 0 & $19.4(0.45)$ & 0 & $24.9(0.52)$ & $5.5(0.23)$ & 0 & 0 & $13.3(0.37)$ & 0 & $18.8(0.44)$ & 0 \\
\hline Zizila & 0 & 0 & $18.8(0.44)$ & 0 & $18.8(0.44)$ & 0 & 0 & 0 & $15.0(0.39)$ & 0 & $20.5(0.47)$ & 0 \\
\hline F100 & 0 & 0 & $11.0(0.33)$ & 0 & $23.3(0.50)$ & 0 & 0 & 0 & $17.7(0.43)$ & 0 & $17.7(0.43)$ & $5.5(0.23)$ \\
\hline Butamu & 0 & 0 & $5.5(0.23)$ & 0 & $17.7(0.43)$ & 0 & 0 & 0 & $24.4(0.51)$ & 0 & $24.4(0.51)$ & 0 \\
\hline Gandajika & 0 & 0 & $16.6(0.41)$ & 0 & $16.6(0.41)$ & $6.6(0.26)$ & 0 & 0 & $16.6(0.41)$ & 0 & $16.6(0.41)$ & 0 \\
\hline $\operatorname{LSD}_{\mathrm{P} \geq 0.05}$ & & - & 0.10 & & 0.10 & & & - & 0.11 & & 0.11 & \\
\hline \multicolumn{13}{|l|}{ Local } \\
\hline Madame & $28.8(0.56)$ & $40.0(0.68)$ & $100.0(1.57)$ & $93.3(1.30)$ & $100.0(1.57)$ & $100.0(1.57)$ & $61.0(0.89)$ & $13.3(0.37)$ & $100.0(1.57)$ & $100.0(1.57)$ & $100.0(1.57)$ & $100.0(1.57)$ \\
\hline Nzaza & $91.7(1.27)$ & $68.8(0.97)$ & $100.0(1.57)$ & $93.3(1.30)$ & $100.0(1.57)$ & $100.0(1.57)$ & $63.8(0.92)$ & 0 & $100.0(1.57)$ & $100.0(1.57)$ & $100.0(1.57)$ & $100.0(1.57)$ \\
\hline Muana mpiana & $20.0(0.46)$ & $17.7(0.43)$ & $93.3(1.3)$ & $82.2(1.13)$ & $100.0(1.57)$ & $100.0(1.57)$ & $88.8(1.23)$ & $22.2(0.49)$ & $100.0(1.57)$ & $100.0(1.57)$ & $100.0(1.57)$ & $100.0(1.57)$ \\
\hline $\begin{array}{l}\text { Kamana } \\
\text { mabanza }\end{array}$ & $33.3(0.61)$ & $17.7(0.43)$ & $93.3(1.3)$ & $80.0(1.10)$ & $100.0(1.57)$ & $100.0(1.57)$ & $72.2(1.01)$ & $11.1(0.33)$ & $100.0(1.57)$ & $100.0(1.57)$ & $100.0(1.57)$ & $100.0(1.57)$ \\
\hline Tshilobo & $63.8(0.92)$ & $38.8(0.67)$ & $100.0(1.57)$ & $91.6(1.27)$ & $100.0(1.57)$ & $100.0(1.57)$ & $52.2(0.80)$ & 0 & $100.0(1.57)$ & $100.0(1.57)$ & $100.0(1.57)$ & $100.0(1.57)$ \\
\hline Kavuandula & $46.6(0.75)$ & $8.30(0.29)$ & $100.0(1.57)$ & $100.0(1.57)$ & $100.0(1.57)$ & $100.0(1.57)$ & $48.8(0.77)$ & $61.0(0.89)$ & $100.0(1.57)$ & $100.0(1.57)$ & $100.0(1.57)$ & $100.0(1.57)$ \\
\hline Luenyi & $60.0(0.88)$ & $46.6(0.75)$ & $100.0(1.57)$ & $100.0(1.57)$ & $100.0(1.57)$ & $100.0(1.57)$ & $55.5(0.84)$ & $22.2(0.49)$ & $100.0(1.57)$ & $100.0(1.57)$ & $100.0(1.57)$ & $100.0(1.57)$ \\
\hline $\begin{array}{l}\text { Mutombo } \\
\text { tshomba }\end{array}$ & $43.8(0.72)$ & $26.1(0.53)$ & $100.0(1.57)$ & $85.0(1.24)$ & $100.0(1.57)$ & $100.0(1.57)$ & $46.6(0.75)$ & $11.1(0.33)$ & $100.0(1.57)$ & $100.0(1.57)$ & $100.0(1.57)$ & $100.0(1.57)$ \\
\hline $\operatorname{LSD}_{\mathrm{P} \geq 0.05}$ & 0.49 & 0.25 & - & 0.51 & - & - & 0.40 & - & - & - & - & - \\
\hline
\end{tabular}

Data were transformed (in parentheses) using formula $y^{\prime}=\arcsin \sqrt{y}$ (Legendre and Legendre, 1998); LSD : Least significant difference; MAP: months after planting 
Table 2. Effect of NPK fertilizer on the Cassava Mosaic Disease gravity using improved and local cassava cultivars in Gandajika, DR-Congo

\begin{tabular}{|c|c|c|c|c|c|c|c|c|c|c|c|c|}
\hline \multirow{3}{*}{ Type of cultivar } & \multicolumn{6}{|c|}{ Site 1 (INERA) } & \multicolumn{6}{|c|}{ Site 2 (Mpiana) } \\
\hline & \multicolumn{2}{|c|}{1 MAP } & \multicolumn{2}{|l|}{3 MAP } & \multicolumn{2}{|l|}{6 MAP } & \multicolumn{2}{|l|}{1 MAP } & \multicolumn{2}{|l|}{3 MAP } & \multicolumn{2}{|l|}{6 MAP } \\
\hline & NPK & NoF & NPK & NoF & NPK & NoF & NPK & NoF & NPK & NoF & NPK & NoF \\
\hline \multicolumn{13}{|l|}{$\begin{array}{l}\text { Improved } \\
\text { TME } 419\end{array}$} \\
\hline TME 419 & 0 & 0 & $16.9(0.42)$ & 0 & $35.2(0.63)$ & $8.1(0.28)$ & 0 & 0 & $17.4(0.43)$ & 0 & $30.7(0.58)$ & 0 \\
\hline Mvuazi & 0 & 0 & $14.7(0.39)$ & 0 & $29.6(0.57)$ & $12.4(0.36)$ & 0 & 0 & $17.4(0.43)$ & 0 & $33.9(0.62)$ & 0 \\
\hline Sadisa & 0 & 0 & $16.7(0.42)$ & 0 & $31.1(0.59)$ & 0 & 0 & 0 & $21.2(0.47)$ & 0 & $41.2(0.69)$ & 0 \\
\hline Disanka & 0 & 0 & $11.5(0.34)$ & 0 & $28.4(0.56)$ & $6.7(0.26)$ & 0 & 0 & $10.4(0.32)$ & 0 & $27.4(0.55)$ & 0 \\
\hline Zizila & 0 & 0 & $28.4(0.56)$ & 0 & $43.7(0.72)$ & 0 & 0 & 0 & $11.0(0.33)$ & 0 & $31.7(0.59)$ & 0 \\
\hline $\mathrm{F} 100$ & 0 & 0 & $16.3(0.41)$ & 0 & $31.7(0.59)$ & 0 & 0 & 0 & $10.9(0.33)$ & 0 & $24.2(0.51)$ & $2.9(0.17)$ \\
\hline Butamu & 0 & 0 & $3.3(0.18)$ & 0 & $22.6(0.49)$ & 0 & 0 & 0 & $15.5(0.40)$ & 0 & $33.2(0.61)$ & 0 \\
\hline Gandajika & 0 & 0 & $23.3(0.50)$ & 0 & $39.5(0.68)$ & $6.7(0.26)$ & 0 & 0 & $15.6(0.40)$ & 0 & $32.6(0.60)$ & 0 \\
\hline $\mathrm{LSD}_{\mathrm{P} \geq 0.05}$ & - & - & 0.13 & - & 0.18 & - & - & - & 0.14 & - & 0.19 & - \\
\hline \multicolumn{13}{|l|}{ Local } \\
\hline Madame & $38.7(0.67)$ & $31.7(0.59)$ & $92.0(1.28)$ & $60.3(0.88)$ & $100.0(1.57)$ & $100.0(1.57)$ & $48.3(0.76)$ & $16.6(0.42)$ & $87.1(1.20)$ & $76.3(1.06)$ & $100.0(1.57)$ & $100.0(1.57)$ \\
\hline Nzaza & $54.1(0.82)$ & $37.9(0.66)$ & $87.4(1.20)$ & $73.8(1.03)$ & $100.0(1.57)$ & $100.0(1.57)$ & $39.6(0.68)$ & 0 & $83.5(1.15)$ & $64.4(0.93)$ & $100.0(1.57)$ & $100.0(1.57)$ \\
\hline Muana mpiana & $15.3(0.40)$ & $22.3(0.49)$ & $60.7(0.89)$ & $50.7(0.79)$ & $100.0(1.57)$ & $100.0(1.57)$ & $61.5(0.90)$ & $11.1(0.33)$ & $100.0(1.57)$ & $75.6(1.05)$ & $100.0(1.57)$ & $100.0(1.57)$ \\
\hline Kamana mabanza & $39.7(0.68)$ & $22.1(0.48)$ & $76.1(1.06)$ & $59.7(0.88)$ & $100.0(1.57)$ & $100.0(1.57)$ & $51.4(0.80)$ & $12.1(0.35)$ & $89.6(1.24)$ & $51.3(0.79)$ & $100.0(1.57)$ & $100.0(1.57)$ \\
\hline Tshilobo & $43.3(0.71)$ & $31.5(0.59)$ & $76.6(1.06)$ & $66.9(0.95)$ & $100.0(1.57)$ & $100.0(1.57)$ & $45.9(0.74)$ & 0 & $82.7(1.14)$ & $53.2(0.81)$ & $100.0(1.57)$ & $100.0(1.57)$ \\
\hline Kavuandula & $34.4(0.62)$ & $9.0(0.30)$ & $70.3(0.99)$ & $47.7(0.76)$ & $100.0(1.57)$ & $100.0(1.57)$ & $45.0(0.73)$ & $36.8(0.65)$ & $95.9(1.36)$ & $78.9(1.09)$ & $100.0(1.57)$ & $100.0(1.57)$ \\
\hline Luenyi & $36.1(0.64)$ & $28.6(0.56)$ & $64.3(0.93)$ & $56.8(0.85)$ & $100.0(1.57)$ & $100.0(1.57)$ & $42.4(0.70)$ & $10.4(0.32)$ & $94.0(1.42)$ & $71.8(1.01)$ & $100.0(1.57)$ & $100.0(1.57)$ \\
\hline Mutombo tshomba & $36.0(0.64)$ & $22.5(0.49)$ & $70.8(1.00)$ & $55.5(0.84)$ & $100.0(1.57)$ & $100.0(1.57)$ & $52.1(0.80)$ & $10.4(0.32)$ & $100(1.57)$ & $72.3(1.02)$ & $100.0(1.57)$ & $100.0(1.57)$ \\
\hline $\operatorname{LSD}_{\mathrm{P} \geq 0.05}$ & 0.38 & 0.37 & 0.18 & 0.17 & - & - & 0.29 & 0.28 & 0.19 & 0.18 & - & - \\
\hline
\end{tabular}

Data were transformed (in parentheses) using formula $y^{\prime}=\arcsin \sqrt{y}$ (Legendre and Legendre, 1998); LSD: Least significant difference; MAP: months after planting 


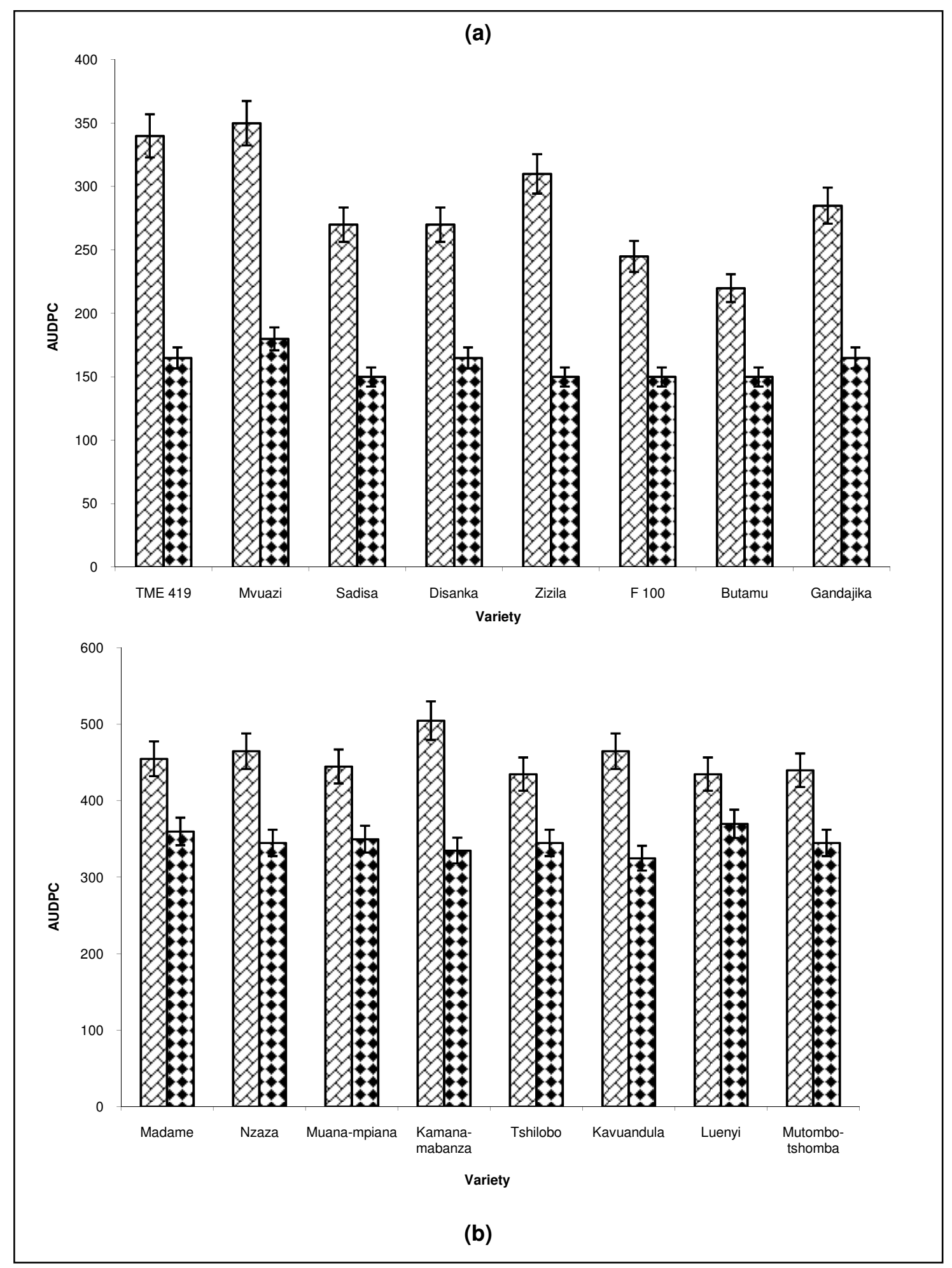

Figure 1. Severity (AUDPC) of Cassava Mosaic Disease at Site 1 (INERA), (a): Improved varieties(b): Local varieties; 降 NPK, 無NoF] 


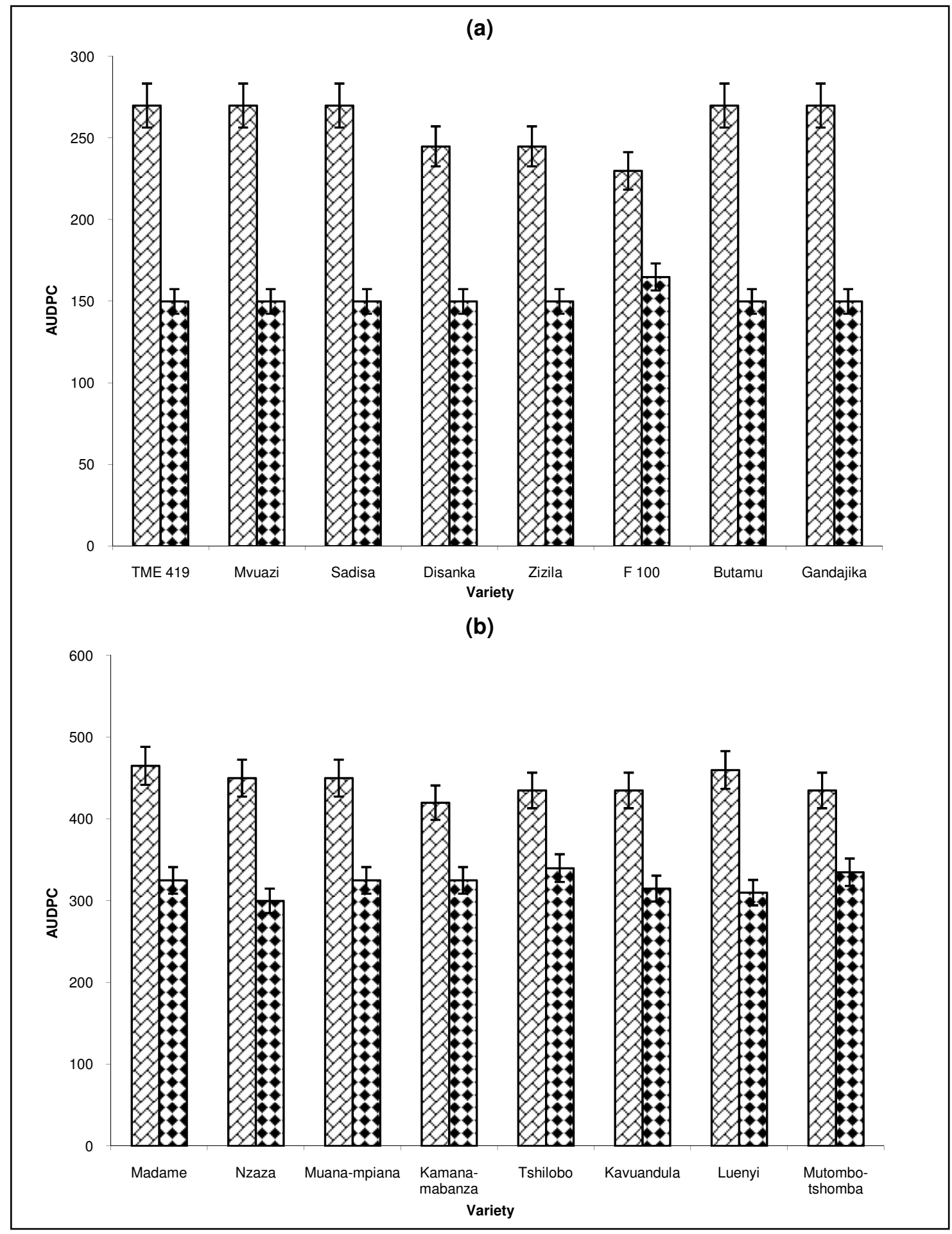

Figure 2. Severity (AUDPC) of Cassava Mosaic Disease at Mpiana-basangana.

(a): Improved varieties (b): Local varieties;逄 NPK, 無NoF] 

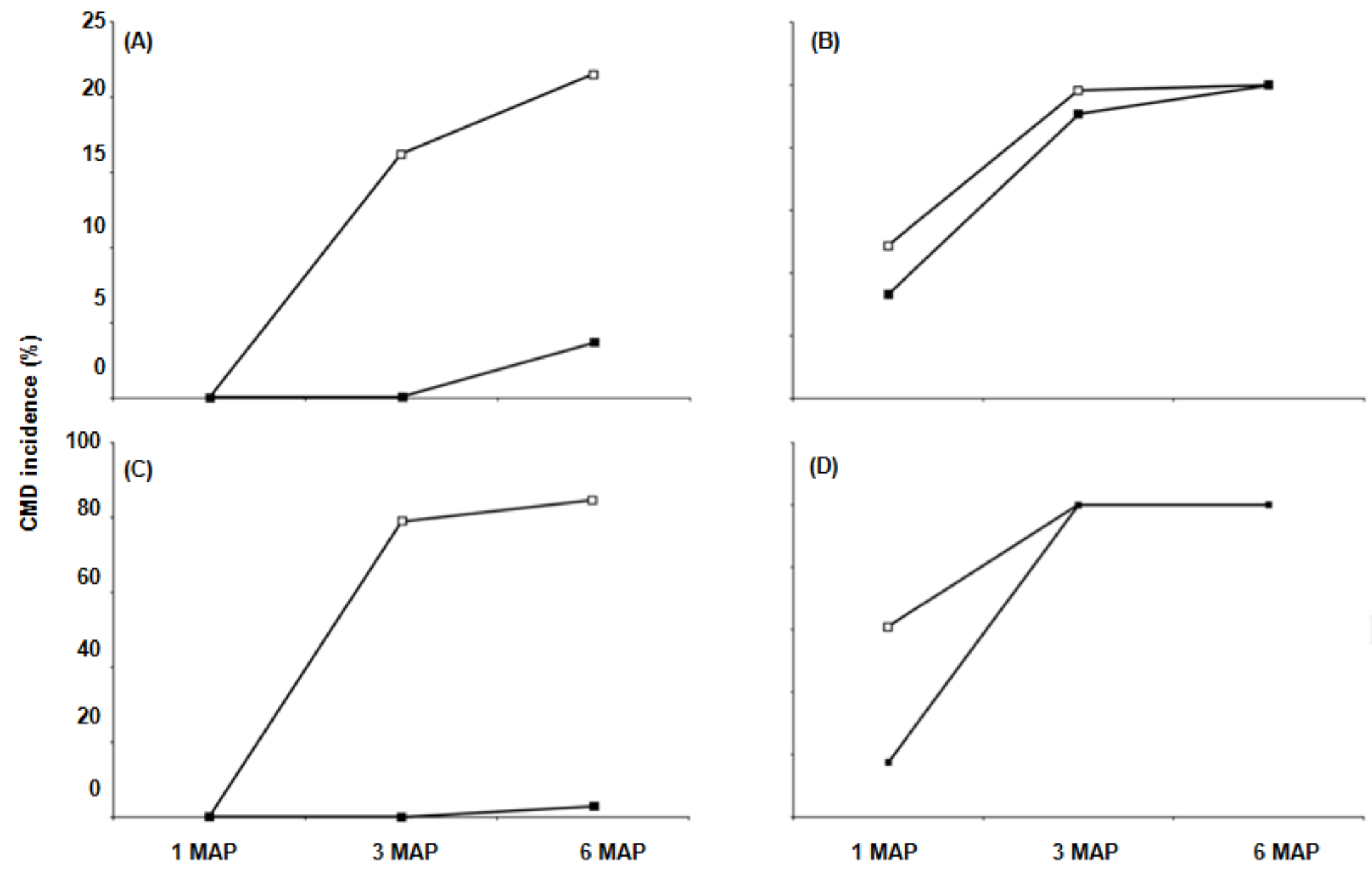

Figure 3.Cassava Mosaic Disease incidence; Improved varieties: (A) Site 1 (INERA), (B) Site 2 (Mpiana); Local varieties: (C) Site 1 (INERA), (D) Site 2 (Mpiana); [ $\square=$ NPK, $\square=$ NoF] 

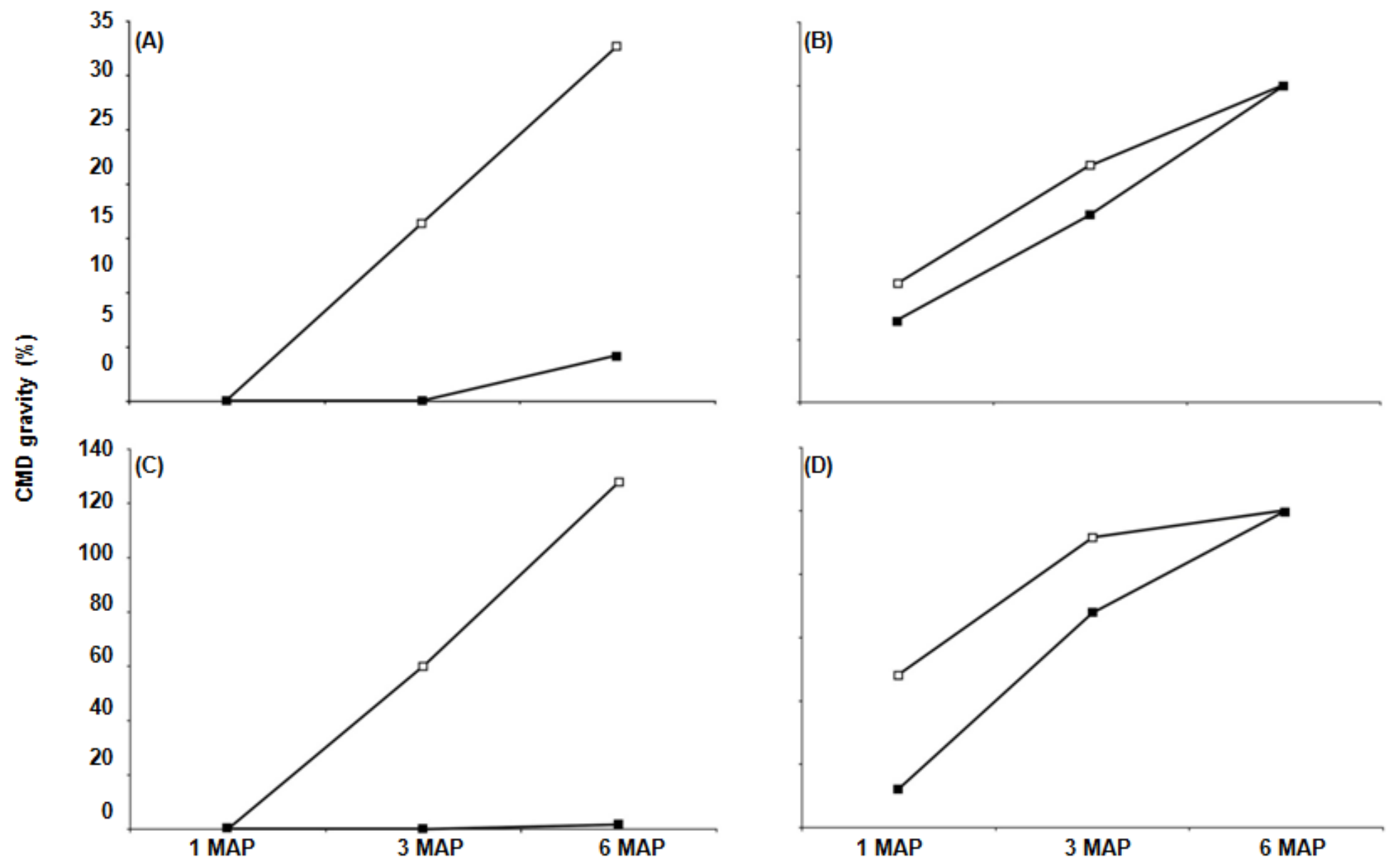

Figure 4. Cassava Mosaic Disease gravity; Improved varieties: (A) Site 1 (INERA), (B) Site 2 (Mpiana); Local varieties: (C) Site 1 (INERA), (D) Site 2 (Mpiana);[ $\square=$ NPK, $=$ NoF] 


\section{DISCUSSION}

This study showed the prevalence of CMD in trials conducted at research station (site 1INERA) and on-farmer environment (site 2 - Mpiana). All cassava varieties did develop typical CMD symptoms at both sites. This confirms that complete resistance to CMD varieties currently available in the DR-Congo is yet to be found.

The CMD incidence remained below $30 \%$ for improved varieties, while it reached $100 \%$ in local varieties (Table 1) during the trials. CMD incidence varied from one site to another and among varieties. This is consistent with previous studies. In fact, several studies conducted on the impact of CMD on cassava in Africa reported that the incidence of this disease varies according to agroecological site, planted varieties, plant age and weather conditions (Abdullahi et al., 2003; Legg et al., 2006; Ntawuruhunga et al., 2007). Arraudeau (1987) suggested that a reduction of nitrogen fertilizer combined with an increase of potassium can limit the effects of CMD. Ogbe et al. (1993) suggested application of a balance NPK fertiliser to cassava varieties susceptible to CMD, to control the incidence and severity of the disease. Sseruwagi et al. (2003) reported that the application of fertilisers did not significantly influence symptom severity for any variety in any season. Their data indicates that CMD spreads less rapidly in low than in high soil fertility conditions. Their finding were recently support by Omorusi and Ayanru, (2011) who indicated that CMD infection was depressed by high dosage of NPK (100 kg ha $\left.{ }^{-1}\right)$ compared to low dosage $\left(10 \mathrm{~kg} \mathrm{ha}^{-1}\right)$. The results of the present study clearly show that CMD incidence, gravity and severity are increased significantly when the recommended NPK dosage of $300 \mathrm{Kg} \mathrm{ha}^{-1}$ was applied. Considering the number of varieties studied and numerous other reports, there is enough evidence to confirm that the application of NPK increases CMD infection regardless of varieties used. This effect of fertilization might be related to the high biomass observed in fertilized plots which, plays an important role in colonization of cassava by Bemisia tabaci (Osiru et al., (1999).

The results reported in the present study indicate that CMD gravity in the two experimental sites for improved varieties remained below $50 \%$ while reaching $100 \%$ for all the local varieties at 6 MAP. This confirms data reported by Adriko et al. (2011) on responses of improved cassava varieties to CMD in Uganda. The severity of CMD expressed by the factor AUDPC indicated variability between varieties and also revealed that the disease has been developed with high degree of severity in plants fertilized compared to trials without fertilization. According to Egesi et al. (2007), the factor AUDPC is very important because it provides a more consistent basis for a reproducible assessment of plant resistance to disease.

Moreover, it was noted that the typical symptoms of CMD are expressed more rapidly in fertilized plots compared to trials without fertilization. In fact, a study conducted in Ivory Coast on mineral fertilization of cassava by Raffaillac and Nedelec (1988) reported that cassava plants subjected to mineral fertilization developed symptoms of CMD in a shorter period of time compared to no fertilized plants. Similarly, in the experimental fields of Makerere University (Uganda), various authors (Sseruwagi, 1998; Osiru et al., 1999; Sseruwagi et al., 2003) had shown that application of NPK increased significantly the incidence of CMD in cassava improved varieties.

In the present study, the local varieties were severely infested by CMD compared to improved varieties. This can be the results of several factors. It is possible that there is a coinfection with multiple viral strains of CMD virus in the study area or the plant materials used 
were from stand that were infected without showing symptoms (Owor et al., 2004). The low incidence, gravity and severity of CMD in cassava improved varieties suggest a presence of CMD tolerance genes. In fact Akano et al. (1997) demonstrated that, cassava improved varieties accumulated genes for resistance to CMD and expressed different levels of resistance which are proportional to the number of genes accumulated.

\section{CONCLUSION}

The incidence, the severity and the gravity of the CMD in the present study are more pronounced in local varieties than improved varieties. NPK fertiliser increases significantly the spread and the expression of the typical CMD symptoms. To minimize the spread of CMD, the use of cassava improved varieties in a large scale and the implementation of a rigorous phytosanitary are needed. Serological and molecular analyses are being conducted to determine the type and the number of strains involved in the CMD infection in the targeted region.

\section{ACKNOWLEDGEMENTS}

We are grateful to the Canadian International Development Agency (CIDA) for the financial support and to the CUI-CUD through the Project KIN 01 (Molecular Biology) for the Doctoral fellowship to MMM. Thanks to Olivier Mulamba and Mbuya Kankonlongo, respectively Director and research Coordinator at the Research Center of the "Institut National pour l'Etude et al. Recherche Agronomiques (INERA/Gandajika)", for providing the cassava plant materials and the experimental sites.

\section{COMPETING INTERESTS}

Authors have declared that no competing interests exist.

\section{REFERENCES}

Abdullahi, I., Atiri, G.I., Dixon, A.G.O. Winter, S., Thottappily, G. (2003). Effects of cassava genotype, climate and the Bemisia tabaci vector population on the development of African Cassava Mosaic Geminivirus (ACMV). Acta Agron. Hung., 51(1), 37 - 46.

Achidi, A.U., Ajayi, O.A., Bokanga, M., Dixon, B.M. (2005).The use of cassava leaves as food in Africa. Ecol. Food Nutr., 44, 423-435.

Adriko, J., Sserubmbwe, W.S., Adipala, E., Bua, A., Thresh, J.M., Edema, R. (2011). Response of improved cassava varieties in Uganda to cassava mosaic disease (CMD) and their inherent resistance mechanisms. Afr. J. Agric. Res., 6(3), 521-531.

Akano, A.O., Atiri, G.I., Ng, S.Y.C., Asiedu, R. (1997). Effect of African cassava mosaic disease on growth and yield components of virus-tested cassava genotypes derived from meristem culture in early and late planting periods in three agro ecologies of Nigeria. Afr. J. Root Tuber Crops, 2(1\&2), 44-48.

Arraudeau, M. (1987). African cassava mosaic disease and its control. In: Proceedings of the International Seminar: African Cassava Mosaic Disease and its Control, CTA, FAO, ORSTOM, IITA, IAPC. Yamoussoukro, 4-8, May 198, Ivory-Coast, Pp. 177-182.

Bawden, F.C. (1960). The multiplication of viruses. In: Horsfall, J.G. and Diamond, A.E. (Eds.). Plant Pathology. Volume II, Academic Press, New York and London, 3, 71-116. 
Dixon, A.G.O.D., Bandyoapadhyay, R., Coyne, D., Ferguson, M., Ferris, R.S.B., Hanna, R., Hughes, J., Ingelbrecht, I., Legg, J., Mahungu, N., Manyong, V., Mowbray, D., Neuenschwander, P., Whyte, J., Hartmann, P., Ortiz, R. (2003). Cassava: from poor farmer's crop to pacesetter of African rural development. Chron. Hort., 43, 8-15.

Egesi, C.N., Ogbe, F.O., Akoroda, M., Ilona, P., Dixon, A. (2007). Resistance profile of improved cassava germplasm to cassava mosaic disease in Nigeria. Euphytica, 155, 215-224.

El-Sharkawy, M.A. (1993). Drought tolerant-cassava for Africa, Asia and Latin America. Breeding projects work to stabilise productivity without increasing pressures on limited natural resources. BioSciences, 43, 441-452.

Fargette, D., Fauquet, C.M. Thouvenel, J.C. (1988). Yield losses induced by African cassava mosaic virus in relation to the mode and date of infection. Trop. Pest Manag, 34, 123133.

FAOSTAT. (2009). FAOSTAT. Available at http://faostat.fao.org (Accessed June, 2010). Food and Agriculture Organization (FAO) of the United Nations, Rome, Italy.

Hahn, S.K, Terry, E.R. Leuschner, K. (1980). Breeding cassava for resistance to cassava mosaic disease. Euphytica, 29, 673-683.

Horst, M. (1990). Relationship between mineral nutrition and plant diseases and pests. Mineral Nutrition of Higher Plants. Academic Press. San Diego, U.S.A., pp. 369-390.

Legendre, P., Legendre, L. (1998). Numerical ecology. 2nd English edition. Elsevier Science $\mathrm{BV}$, Amsterdam, $\mathrm{xv}+853$ pages.

Legg, J.P, Thresh, J.M. (2000). Cassava mosaic virus disease in East Africa: a dynamic disease in a changing environment. Virus Res., 71, 135-149.

Legg, J.P., Owor, B., Sseruwagi, P. Ndunguru, J. (2006). Cassava mosaic virus disease in East and Central Africa: epidemiology and management of a regional pandemic. Adv. Virus Res., 67, 355-418.

Lema, K.M., Tata-Hangy, K., Bidiaka, M. (2004). Management of African root and tuber scale using improved cassava genotypes and mineral fertilizers. Afr. Crop Sc. J., 12, 217-221.

Nassar, N.M.A., Ortiz, R. (2007). Cassava improvement: challenges and impacts. J. Agric. Sc., 145, 163-171.

Ntawuruhunga, P., Ssemakula, G., Ojulong, H., Bua, A., Ragama, P. Kanobe, C. Whyte, J. (2006). Evaluation of advanced cassava genotypes in Uganda. Afr. Crop Sci. J., 14(1), 17-25.

Ntawuruhunga, P., Okao-Okuja, G., Bembe, M. Obambi, A., Armand Mvila, J.C., Legg, J.P. (2007). Incidence and severity of cassava mosaic disease in the Republic of Congo. Afr. Crop Sci. J., 15(1), 1-9.

Oerke, E.C., (2006). Crop losses to pests. J. Agr. Sc., 144, 31-43.

Ogbe, F.O., Atiri, G.I., Dixon, A.G.O., Thottappilly, G. (2003). Serological and biological variations of African cassava mosaic virus in Nigeria. Ann. Appl. Biol., 143, 203-213.

Ogbe, F.O., Ohiri, A.C., Nnodu. E.C. (1993). Effect of NPK fertilization on symptom severity of African cassava mosaic virus. Int. J. Pest Manag, 39, 80-83.

Omorusi, V.I., Ayanru. D.K.G. (2011). Effect of NPK fertilizer on diseases, pests, and mycorrhizal symbiosis in Cassava. Int. J. Agric. Biol., 13, 391-395.

Osiru, D.S.O., Sserubombwe, W.S., Sseruwagi, P., Thresh, M., Otim-Nape, G.W. (1999). Effects of cassava mosaic virus disease on the growth and yield of cassava - some highlights from Makerere experiments. Afr. Crop Sc. J., 7(4), 511-522.

Otim-Nape, G.W., (1987). Importance, production and utilisation of cassava in Uganda. In: Proceedings of the International Seminar: African Cassava Mosaic Disease and its Control. CTA, FAO, ORSTOM, IITA, IAPC. Yamoussoukro, Côte d'Ivoire, 7-8 May 1987, pp. 203-218. 
Owor, B., Legg, J.P., Okao-Okuja, G., Obonyo, R.R., Ogenga-Latigo, M.W. (2004). The effect of cassava mosaic geminivirus on symptom severity, growth and root yield of a cassava mosaic virus disease-susceptible cultivar in Uganda. Ann. Appl. Biol., 145, 331-337.

Raffaillac, J.P., Nedelec, G. (1988). Quelques effets de la mosaïque africaine du manioc (MAM) sur les premiers stades de croissance du manioc. Documents ORSTOM, Centre ORSTOM d'Adiopodoumé, Abidjan, pp. 267-275.

Shaner, G., Finney, R.E. (1977). The effect of nitrogen fertilization on the expression of slowmildewing resistance in Knox wheat. Phytopathology, 67, 1051-1056.

Sseruwagi, P. (1998). Influence of NPK fertilizer on disease spread, growth and yield of cassava mosaic disease affected plants. M.Sc. Thesis, Makerere University, Kampala, $103 p p$.

Sseruwagi, P., Otim-Nape, G.W., Osiru, D.S.O., Thresh, J.M. (2003). Influence of NPK fertiliser on populations of the whitefly vector and incidence of cassava mosaic virus disease. Afr. Crop sc. J., 11(3), 171-179.

Tata-Hangy, K., Legg, J., Hanna, R., Toko, M., Lema, K.M., Dixon, A., Mahungu, N.M. (2007). Incidence and distribution of cassava diseases and pests in theDemocratic Republic of Congo. Proceedings: 9th ISTRC-AB Symposium,Kenya, 2004, 614- 622.

Thresh, J.M., Otim-Nape, G.W., Legg, J.P., Fargette, D. (1997). African cassava mosaic virus disease: the magnitude of the problem. Afr. J. Root Tuber Crops, 2, 11-17.

(C) 2012 Muengula-Manyi et al.; This is an Open Access article distributed under the terms of the Creative Commons Attribution License (http://creativecommons.org/licenses/by/3.0), which permits unrestricted use, distribution, and reproduction in any medium, provided the original work is properly cited. 